\title{
Lymph node status as a guide to selection of available prognostic markers in breast cancer: the clinical practice of the future? A Elzagheid ${ }^{* 1,2}$, T Kuopio ${ }^{3}$, S Pyrhönen ${ }^{1}$ and Y Collan ${ }^{2}$
}

Address: ${ }^{1}$ Department of Oncology and Radiotherapy, Turku University Hospital, Savitehtaankatu 1 PB 52, FIN-20521, Turku, Finland, ${ }^{2}$ Department of Pathology, University of Turku, and Turku University Hospital, Kiinamyllynkatu 10, FIN-20520, Turku, Finland and ${ }^{3}$ Department of Pathology, Jyväskylä Central Hospital, FIN-40620, Jyväskylä, Finland

Email: A Elzagheid* - adibel@utu.fi; T Kuopio - teijo.kuopio@ksshp.fi; S Pyrhönen - seppo.pyrhonen@tyks.fi; Y Collan - ycollan@utu.fi

* Corresponding author

Published: 08 November 2006

Diagnostic Pathology 2006, I:4I doi:I0.II86/I746-I596-I-4I
Received: 28 June 2006

Accepted: 08 November 2006

This article is available from: http://www.diagnosticpathology.org/content/I/I/4I

(c) 2006 Elzagheid et al; licensee BioMed Central Ltd.

This is an Open Access article distributed under the terms of the Creative Commons Attribution License (http://creativecommons.org/licenses/by/2.0), which permits unrestricted use, distribution, and reproduction in any medium, provided the original work is properly cited.

\begin{abstract}
Prognosticators evaluating survival in breast cancer vary in significance in respect to lymph node status. Studies have shown e.g. that HER2/neu immunohistochemistry or HER2/neu gene amplification analysis do perform well as prognosticators in lymph node positive $(\mathrm{LN}+)$ patients but are less valuable in lymph node negative ( $\mathrm{LN}$-) patients. We collected data from different studies and tried to evaluate the relative significance of different prognosticators in $\mathrm{LN}+/ \mathrm{LN}$ patient groups. In $\mathrm{LN}+$ patients HER2/neu and E-cadherin immunohistochemistry were the statistically most significant prognosticators followed by proliferation associated features (mitotic counts by SMI (standardised mitotic index) or MAI (mitotic activity index), or S-phase fraction). Bcl2 immunohistochemistry was also significant but $\mathrm{p} 53$ and cystatin $A$ had no significance as prognosticators. In LN- patients proliferation associated prognosticators (SMI, MAI, Ki-67 index, PCNA immunohistochemistry, S-phase fraction) are especially valuable and also Cathepsin D, cystatin $\mathrm{A}$, and $\mathrm{p} 53$ are significant, but HER2/neu or bcl-2, or E-cadherin less significant or without significance. We find that in studies evaluating single prognosticators one should distinguish between prognosticators suitable for $\mathrm{LN}+$ and $\mathrm{LN}$ - patients. This will allow the choice of best prognosticators in evaluating the prospects of the patient. The distinction between $\mathrm{LN}+$ and $\mathrm{LN}$ patients in this respect may also be of special value in therapeutic decisions.
\end{abstract}

\section{Background}

Breast cancer is the most common cancer among women and the second leading cause of cancer deaths in women today. For example, 212,920 new cases of invasive breast cancer are expected to be diagnosed among women in the United States in 2006 (1.4 new cases among 1000 women) [1]. In Finland, according to the Finnish Cancer Registry, about 3800 females are diagnosed with breast cancer every year (1.5 new cases among 1000 women)[2]. Improved methods of detection and treatment of breast cancer have had a significant influence on disease out- come [3]. The main challenge today is to find factors which could predict the patients who have a tumor with aggressive nature. There are a lot of data on clinical prognostic factors such as axillary lymph node (LN) status, tumor size, histological grade, and clinical stage. Breast cancer treatment could be based on these factors [4]. However, additional factors have also been used such as estrogen receptor (ER) positivity, progesterone receptor (PR) positivity, and HER2/neu status. The latter are considered especially useful in identifying patients who benefit from systemic adjuvant therapy. The International 
Consensus Panel of St. Gallen determined the standard prognostic factors of breast cancer as follows: LN status, ER and PR, tumor size, histological grade, and age [5]. These prognostic factors have been used to identify the high-risk patients who may benefit from the adjuvant systemic therapy. However, still there is an urgent need for finding biological factors which could help in planning the future therapy of breast cancer.

Here we review several biological prognostic factors and associate their prognostic role with the lymph node status. Such grouping could help clinicians to create tailored and more individualized prognostic models which could help in choosing the right treatment for individual patients. Earlier research has shown that prognosticators vary between $\mathrm{LN}+$ and $\mathrm{LN}$ - patients. Table 1 shows the characteristics of a few studies we will refer to in the following.

Differences in the size and other characteristics of the studied populations make comparison between different reports difficult. Most of the studied populations are Caucasian (white), but in two American studies, there is also a fraction of black patients $[37,68]$. Because populations may differ in prognostic characteristics, we have decided to stress this point $[1,65]$. Most studies do not include adjustment for age and there are studies which do not necessarily clearly describe how cutpoints for each prognostic marker were defined. [In writing this review, however, we have expected that the authors have been able to select the most significant cutpoint for each prognosticator studied (see e.g. [123])].

\section{Oncogenes and tumor suppressor genes \\ C-erbB-2 (HER2) or HER2/neu}

HER2/neu proto-oncogene encodes a 185-KDa transmembrane glycosylated epidermal growth factor receptor that contains an extracellular domain and has intracellular tyrosine kinase activity [6]. Amplification of the HER2/ neu gene and overexpression of its protein are known to be characteristic of many breast cancers [7-9]. Several

Table I: Survival associated tissue-section-based prognostic factors and lymph node status in breast cancer.

\begin{tabular}{|c|c|c|c|c|c|c|c|c|c|}
\hline Prognosticator & $\mathbf{N}$ & $\begin{array}{l}\text { Age range } \\
\text { or median }\end{array}$ & Country & Methods & $\begin{array}{l}\text { Stage/LN status } \\
\text { of all patients }\end{array}$ & $\begin{array}{l}\text { Stength of } \\
\text { association } \\
\text { (survival \%)* }\end{array}$ & $\begin{array}{l}\text { P value, type } \\
\text { of analysis }\end{array}$ & $\begin{array}{l}\text { Mean or median } \\
\text { follow-up (months) }\end{array}$ & Reference \\
\hline \multicolumn{10}{|l|}{ LN+ patients } \\
\hline AgNOR & 164 & N.A. & Italy & MA & $\mathrm{N}-, \mathrm{N}+$ & DFS $(42,61)$ & $0.0093 \mathrm{M}$ & 108 & Derenzini90 \\
\hline $\mathrm{Bcl}-2$ & 107 & 56 & Belgium & $\mathrm{IHC}$ & $\mathrm{N}-, \mathrm{N}+$ & DFS $(21,62)$ & $<0.001 \mathrm{U}$ & 91 & Hellemans $s^{55}$ \\
\hline CD44 & 74 & 62 & Finland & $\mathrm{IHC}$ & $\mathrm{N}-, \mathrm{N}+$ & DSS $(45,56)$ & $0.02 \mathrm{U}$ & 84 & Joensuu ${ }^{158}$ \\
\hline E-cadherin & 57 & 59 & Finland & $\mathrm{IHC}$ & $\mathrm{N}-, \mathrm{N}+$ & OS $(36,88)$ & $0.0001 \mathrm{U}$ & 66.5 & Elzagheid 150 \\
\hline EGFR & 404 & 53.4 & Japan & $\mathrm{IHC}$ & $\mathrm{N}-, \mathrm{N}+$ & DFS $(50,75)$ & $<0.0001 \mathrm{U}$ & 46 & Tsutsuil110 \\
\hline ER & 705 & 54 & UK & $\mathrm{IHC}$ & I-IV & DFS, ReR 0.651 & $0.004 \mathrm{M}$ & 62 & Rehim $^{122}$ \\
\hline HER2/neu & 106 & 59 & Finland & $\mathrm{IHC}$ & $\mathrm{N}-, \mathrm{N}+$ & OS $(13,80)$ & $0.001 \cup$ & 67.2 & Jalava $^{16}$ \\
\hline IGF-I & 98 & 57.1 & Finland & $\mathrm{IHC}$ & $\mathrm{N}-, \mathrm{N}+$ & OS $(16,35)$ & $0.0286 \mathrm{U}$ & 169.2 & Toropainen 115 \\
\hline Mitoses & $|3|$ & 59 & Finland & SMI & $\mathrm{N}-, \mathrm{N}+$ & RR 3.5 & $0.0005 \mathrm{U}$ & 69 & Kronqvist ${ }^{71}$ \\
\hline Mitoses & 368 & $25-81$ & $M C$ & MAI & $\mathrm{N}+$ & OS $(57,83)$ & $0.00003 \mathrm{U}$ & 60 & Simpson 68 \\
\hline P2I & 328 & N.A. & USA & $\mathrm{IHC}$ & $\mathrm{N}-, \mathrm{N}+$ & DFS, $X^{2} 74.61$ & $0.054 \mathrm{M}$ & 195.6 & Thor 37 \\
\hline $\mathrm{PgR}$ & 106 & 58 & Finland & $\mathrm{IHC}$ & $\mathrm{N}-, \mathrm{N}+$ & N.A. & 0.0186 & 70 & Jalava 123 \\
\hline SPF & 257 & $25-81$ & $M C$ & FCM & $\mathrm{N}+$ & OS $(70,82)$ & $0.026 \mathrm{U}$ & 60 & Simpson 68 \\
\hline \multicolumn{10}{|l|}{ LN-patients } \\
\hline Ploidy & 50 & 56 & UK & FCM & $\mathrm{N}-$ & DFS $(32,7 I)$ & $<0.0001 \cup$ & $>120$ & Yuan 132 \\
\hline Cathepsin D & 262 & 60 & Finland & $\mathrm{IHC}$ & $\mathrm{N}-$ & DFS $(47,68)$ & $<0.0001 \mathrm{U}$ & 98.4 & Isola 100 \\
\hline CD44 & 237 & 56 & Holland & $\mathrm{IHC}$ & $\mathrm{N}-, \mathrm{N}+$ & DFS $(50,75)$ & $0.005 \mathrm{U}$ & 84 & Foekens $^{156}$ \\
\hline EGFR & 618 & 53.4 & Japan & $\mathrm{IHC}$ & $\mathrm{N}-, \mathrm{N}+$ & DFS, ReR 2.05 & $0.0241 \mathrm{M}$ & 46 & Tsutsuil 10 \\
\hline HER2/neu & 324 & N.A. & USA & FISH & $\mathrm{N}-$ & DFS $(57,75)$ & $0.0077 \cup$ & 50 & Press ${ }^{17}$ \\
\hline HER2/neu & 224 & 59 & Finland & $\mathrm{IHC}$ & $\mathrm{N}-, \mathrm{N}+$ & N.A. & N.S. & 67.2 & Jalava ${ }^{16}$ \\
\hline $\mathrm{Ki}-67$ & 89 & 60.5 & Finland & $\mathrm{IHC}$ & $\mathrm{N}-, \mathrm{N}+$ & OS $(50,70)$ & $0.0297 \cup$ & 103.2 & Pietilainen 78 \\
\hline Mitoses & 516 & $<55$ & $M C$ & MAI & $\mathrm{N}-$ & DFS $(62,85)$ & $<0.00001 \mathrm{U}$ & 118 & Baak $^{69}$ \\
\hline Mitoses & 232 & 59 & Finland & SMI & $\mathrm{N}-, \mathrm{N}+$ & RR 4.2 & $0.0007 \cup$ & 69 & Kronqvist $^{71}$ \\
\hline $\mathrm{P} 27$ & 75 & $<65$ & Canada & $\mathrm{IHC}$ & $\mathrm{N}-, \mathrm{N}+$ & DSS, ReR 0.24 & $0.03 \mathrm{M}$ & 180 & Foulkes ${ }^{47}$ \\
\hline P53 & 700 & $<50$ & USA & $\mathrm{IHC}$ & $\mathrm{N}-$ & DFS $(53,85)$ & $0.000 I U$ & 54 & Allred ${ }^{33}$ \\
\hline PCNA & 205 & 60.5 & Finland & $\mathrm{IHC}$ & $\mathrm{N}-$ & DFS $(56,80)$ & $0.0003 \cup$ & 141.6 & Aaltomaa ${ }^{84}$ \\
\hline SPF & 180 & N.A. & China & N.A. & $\mathrm{N}-$ & N.A. & $<0.001$ & 60 & Zhang 96 \\
\hline
\end{tabular}

Prognosticators for $\mathrm{LN}+$ patients are presented first followed by those for $\mathrm{LN}$ - patients. The database applied was PubMed, the presented papers were published during years 199|-2005. The most significant $p$-values with defined survival characteristics for each marker are shown. P-values are not comparable with each other in absolute terms because also the size of the sample influences the $p$ value. The value of prognosticators can only be compared reliably by comparing different prognosticators in the same patient material.

* The figures within the parantheses refer to the survival of 2 cutpoint-associated patient groups after median follow up. IHC, immunohistochemistry; $\mathrm{N}$-, node negative; $\mathrm{N}+$, node positive; MA, morphometric analysis; FCM, flow-cytometry; NA, not available; MC, multicenter study; SMI, standardized mitotic index; MAI, mitotic activity index; OS, overall survival; DFS, disease free survival; DSS, disease specific survival; RR, risk ratio; ReR, relative risk; $X^{2}$, Chi square; $F I S H$, fluorescence in situ hybridization; N.S, not significant; $M$, multivariate; $U$, univariate. 
studies have correlated the overexpression of the HER2/ neu oncogene with poor prognosis in breast cancer patients $[10,11]$, and demonstrated that evaluating HER2/ neu protein by immunohistochemistry (IHC), fluorescence in situ hybridization (FISH), and chromogenic in situ hybridization (CISH) are important in selecting optimal therapy and predicting prognosis in breast cancer patients [12-14]. Slamon et al. and Jalava et al. [15,16], showed that intensive HER2/neu immunostaining was a highly significant negative prognosticator in $\mathrm{LN}+$ patients (especially postmenopausal), but not a significant prognosticator among LN- patients or patients younger than 52 years. The paper of Jalava et al. [16] suggested that the size of the patient group which absolutely seemed to need the targeted therapy against the amplified HER2/neu receptor was at least $2 \%$ of all breast cancer patients. Press et al. [17], however, suggested that HER2/neu is a significant prognosticator in LN- patients. However, there is still no perfect consensus on which method is most predictive of positive patient response to trastuzumab, also known as Herceptin, a monoclonal antibody that selectively targets HER2/neu. Tawfik et al. [18] discussed the results from a study comparing HER2/neu expression and gene amplification in the same patients by IHC using automated cellular imaging system (ACIS) and by FISH. They concluded that HER2/neu assessment by IHC-ACIS correlates highly with results obtained by FISH. The concordance rate between two methods was $94 \%$. Isola et al. [19] showed that CISH could provide an accurate and practical alternative to FISH for clinical diagnosis of HER2/neu oncogene amplification in archival formalin-fixed breast cancer samples. Seidman and associates [20] reported that the overall response rate (for combination paclitaxel and trastuzumab) in patients with HER2/neu overexpression ranged from $67 \%$ to $81 \%$, compared with $41 \%$ to $46 \%$ in patients with tumors having normal Her-2 expression. In agreement with them Joensuu et al., Piccart-Gebhart et al., and Romond et al. [21-23] demonstrated positive response among patients showing HER2/neu amplification or intensive membrane staining by immunohistochemistry. The effect was clear in disease-free- survival and overall survival in freedom from distant metastases.

\section{P53}

Early observations after the identification of the p53 protein suggested that $\mathrm{p} 53$ functioned as an oncogene. In fact it does, but only in the mutated form. In the late 1980s, however, several discoveries proved that the normal function of p53 was anti-oncogenic. One of the several functions of the normal p53 gene is suppression of cell proliferation. When DNA is damaged p53 inhibits the progression of cell cycle from G1 to the S-phase or during S-phase [24-26]. The mutation of the p53 gene has been detected in almost 50\% of human cancers including breast cancer [27-29]. Several studies demonstrated that mutations of $\mathrm{p} 53$ or increased nuclear expression of $\mathrm{p} 53$ protein is a prognostic factors in breast cancer, and associated with worse prognosis [30-32]. Allred and associates [33] showed that p53 predicted disease free survival in patients with LN- breast cancer. Expression of mutant p53 protein was associated with early disease recurrence and early death in LN- breast cancer. The results of Kuopio et al. [34] clearly support the latter finding. In their series immunohistochemical positivity of p53 was a significant prognosticator among all and $\mathrm{LN}$ - patients, but did not show significance among $\mathrm{LN}+$ patients.

\section{P2I}

p21 (WAF) is an inhibitor of cyclin-dependent kinase. It plays a central role both in the regulation of the cell cycle and in the DNA replication [35]. p21 (WAF) is regarded as a putative tumor suppressor and its role in breast cancer is still unclear. p21 (WAF) might have a functional role in the inhibition of PCNA mediated DNA replication [35]. So far there is not much evidence that p21 (WAF) could be used as a prognostic factor in breast cancer [36]. Thor and co-workers demonstrated marginal independent prognostic significance of the p21 (WAF) in the $\mathrm{LN}+$ set of patients, whereas p21 status was not significantly associated with survival among LN-patients [37]. Ras p21 is a guanine nucleotide-binding protein that is involved in the signal transduction pathway that control cell proliferation $[38,39]$. The ras gene is rarely mutated in breast tumors, but is overexpressed in $50-60 \%$ of breast tumors [40]. Rundle et al. suggested that the presence of ras p21 in blood is associated with a five fold increased risk of breast cancer [41]. Czerniak et al. found that p21 expression was significantly higher in cancer cells than in epithelial cells of control specimens. As a group, tumors with axillary lymph node metastases expressed higher levels of ras p21 than nonmetastasizing tumors [42].

\section{P27}

P27 is a cyclin dependent kinase inhibitor, which may act as a potential suppressor gene. Reduction of p27 expression is related to uncontrolled cell proliferation and tumorigenesis. P27 acts in G1 to inhibit cyclin-cdks $[43,44]$. Several studies have suggested that low expression of p27 is an independent factor weakly associated with poor prognosis [45,46]. Foulkes and his co-workers (2004) [47] demonstrated that the level of p27 was one of independent predictors in $\mathrm{LN}$ - patients but not in $\mathrm{LN}+$ patients.

\section{C-myc}

Amplification of the c-myc gene is found in 20\% of primary breast cancers, and this is more frequent in larger tumors, and in lymph node positive patients [48]. Overexpression and other alterations of c-myc gene may be related to breast cancer progression. It can be expected 
that c-myc has a potential as a marker of poor prognosis $[49,50]$. We did not find c-myc associated prognostic information which was related to the lymph node status.

\section{BCl-2}

$\mathrm{Bcl}-2$ gene encodes for a mitochondrial protein thought to prevent apoptosis in normal cells. Dysregulation of this gene can contribute to tumor progression and increased drug resistance [51,52]. Bcl-2 expression was associated with favourable prognosis in breast cancer and was both estrogen receptor(ER) and progesterone receptor (PR) associated [53,54]. Several studies have demonstrated the independent favourable prognostic impact of Bcl-2 on breast cancer particularly among $\mathrm{LN}+$ patients $[55,56]$. It is obvious that the prognostic value of $\mathrm{Bcl}-2$ staining among all patients is solely based on prognostic applicability among $\mathrm{LN}+$ patients because the association among LN- patients is clearly non significant [57].

\section{Cell proliferation}

Mitotic count

Evaluation of proliferation activity of the neoplastic cells gives important prognostic information, especially in breast cancer $[58,59]$. There are many available ways to measure cell proliferation, including the determination of the mitotic rate by counting the mitotic figures $[60,61]$. Mitotic counts are performed by counting the number of mitoses from ten high power fields (Baak et al. ; mitotic activity index; MAI), or by expressing the count by square millimeter, which produces the standardised mitotic index (SMI) [62], or volume fraction corrected mitotic index $\left(\mathrm{M} / \mathrm{V}_{\mathrm{v}}\right.$ index $)[63,64]$. Many studies demonstrated that the MAI is an independent prognostic factor for recurrence free survival $[65,66]$. SMI is a bit more efficient than MAI as a prognosticator [67]. Simpson et al. [68] showed that determination of mitotic activity is able to identify a group with improved disease free and overall survival among patients with $\mathrm{LN}+$ breast cancer. The mitotic activity is also an independent prognostic marker in LN- breast cancer patients younger than 55 years [69]. Baak and his co-worker also found that the LN- patients with MAI > 10 are at risk for distant metastases, similar to LN+ [70]. SMI was a highly significant prognosticator among all patients but especially among LN- patients [71]. Among LN+ patients this marker was less significant. It is surprising in light of numerous ways to measure proliferative activity how consistently the mitotic count emerges as the most powerful prognosticator. All ways of estimation are prognosticators but the mitotic count is the strongest one in the majority of comparing studies.

\section{$\mathrm{Ki}-67$}

$\mathrm{Ki}-67$ antigen is one of several cell-cycle regulating proteins which can be determined by immunohistochemistry $[72,73]$. It is expressed in proliferating G1-, S- and G2/M- phase nuclei $[74,75]$. Because most of the Ki-67 positive cells are in the cell cycle, Ki-67 labelling index (fraction of Ki-67 positive nuclei of all nuclei) reflects the fraction of proliferating cells. Many studies demonstrated the association between a high Ki-67 labelling index, histological grade and large tumor size in breast carcinoma $[76,77]$. Ki-67 labelling index (determined e.g. by the MIB1 antibody; an IgG monoclonal antibody used for detection Ki67) has prognostic value in breast cancer, particularly in LN- patients $[78,79]$. However, the prognostic significance is less than that of mitotic count (as determined with either MAI or SMI). However, there is some evidence that 3-dimensional analysis of Ki-67-positive nuclei may improve the prognostic power of Ki-67 immunohistochemistry [80].

\section{PCNA}

Proliferating cell nuclear antigen (PCNA) is a DNApolymerase-related protein which is expressed in all proliferating cells. The expression is increased during G1 phase, S-phase and declines during G2/M [81]. Many reports observed that PCNA shows prognostic value in breast cancer $[82,83]$. Aaltomaa and his coworkers stated that the prognostic significance of PCNA can be demonstrated especially among LN- patients [84]. They did not include $\mathrm{LN}+$ patients in their study.

\section{AgNOR}

Argyrophilic nucleolar organizer regions (AgNOR) correlate with the proliferative activity of neoplasms. Increased AgNOR counts may reflect increased proliferative activity of cells $[85,86]$. AgNOR counts have been studied in breast carcinoma, but the results have been conflicting. Some studies have demonstrated that quantitative analysis of AgNORs yields a prognostic factor in breast cancer $[87,88]$. The combination of MIB-1- immunopositivity and AgNOR measurements in MIB-1 positive nuclei improves prognostication [89]. Derenzini et al. reported that AgNOR has a prognostic value specially among $\mathrm{LN}+$ patients [90]. Others were not able to find prognostic significance in AgNOR counts for breast cancer [91,92].

\section{S-phase fraction (SPF)}

The histogram describing the nuclear DNA content determined by flow cytometry can be used as an estimate of the proliferation rate. The measurement estimates the fraction of cells in the $S$ phase (S phase fraction), which reflects proliferative activity. The S-phase fraction (SPF) is a rough estimate of neoplastic growth rate. Several reports observed the prognostic value of SPF in breast cancer $[93,94]$. Low SPF is associated with an excellent prognosis in LN- breast patients [95-97]. Based on the grading efficiency analysis [98] SPF estimation from isolated nuclei may reach efficiencies comparable to that of mitotic counts. 


\section{Cathepsin D (CD)}

Cathepsin D is a 52-kd protein, precursor to a lysosomal acidic protease. This proteolytic enzyme can degrade basement membranes. It has mitogenic activity on MCF-7 cells that are estrogen depleted and contributes to proliferation, invasion, and progression in breast [99]. Several studies have demonstrated that Cathepsin D is an important prognostic factor in breast cancer, especially in LNpatients $[100,101]$. In the report by Rochefort [102] overexpression of cathepsin D was associated with increased risk of metastasis, but there are also studies that failed to find prognostic significance of cathepsin D in breast cancer $[103,104]$.

\section{Growth factors}

Epidermal growth factor receptor (EGFR)

EGFR is a member of the tyrosine kinase growth factor receptor family. EGFR and its ligand, transforming growth factor-alpha (TGF-alpha) play an important role in several human cancers $[105,106]$, through the autocrine growthregulation system in breast cancer, EGFR has been reported to be associated with a poor clinical outcome $[107,108]$. Rampaul and his co-workers found that the EGFR was significant only in lymph node positive breast cancer patients [109], with high expression reflecting worse outcome. Tsutsui et al. reported that a combination of EGFR and ER was an independent significant factor for both disease free survival (DFR) and overall survival (OS) both in patients with $\mathrm{LN}$ - and $\mathrm{LN}+$ breast cancer. Patients with EGFR (+) and ER (-) had worse DFS and OS [110].

\section{Insulin-like growth factor (IGF)}

IGF1 and IGF2 are circulating peptide hormones and locally acting growth factors with both paracrine and autocrine functions. Both IGF1 and IGF2 are involved in the regulation of cell proliferation and apoptosis [111]. Many observers suggested that IGFs are involved in the progression of breast cancer $[112,113]$. The presence of IGF-1 immunoreactivity in breast cancer epithelial cells indicates a lower degree of malignancy than the lack of IGF1 [114]. Toropainen et al. reported that, in a univariate analysis, IGF-1 was significantly related to a high survival probability particularly in $\mathrm{LN}+$ breast cancer patients [115].

\section{Estrogen (ER) and progesterone (PR) receptors}

Since breast cancer is one of the hormone dependent tumors much attention has been paid to the relationship between ER and PR and breast cancer. The study by Blanco et al. (1984) [116] showed that ER+ PR+ patients had better prognosis than ER- PR- patients. In late 1970's and early 1980 's the measurement of ER as well as PR became standard practice in the prediction of the outcome of breast cancer patients [117-119]. The immunohistochemical analysis of ER and PR has replaced the traditional and also clinically validated dextran charcoal radioactive ligand binding assay [120]. The prognostic value of ER and PR seems to be greater among axillary $\mathrm{LN}+$ than among LN- patients $[121,122]$. The study of Jalava et al. [123] showed that immunohistochemical ER score is associated with prognosis. However, cutpoints for defining the groups with good or worse prognosis may differ between $\mathrm{LN}-$ and $\mathrm{LN}+$ patients.

\section{DNA content}

Cytometric quantitation of nuclear DNA content can assist in the diagnosis and grading of malignant tumors [124]. A great number of studies using flow cytometry and static image cytometry suggested that nuclear DNA content has a significant value in prognosis of breast cancer [125-127]. Tumors with DNA peaks within diploid limits have a more favorable prognosis than those with aneuploid peaks $[128,129]$. Nuclear DNA content strongly correlated to histopathologic grade of ductal carcinoma. Histologic grade 3 tumors were more likely to be aneuploid than others $[130,131]$. Many observers stated that aneuploid tumors were associated with a poorer prognosis than diploid tumors in LN- breast cancer patients $[132,129]$. However, an adverse correlation was stated by Chassevent et al. They confirmed that ploidy status had no prognostic impact in the overall population or in subgroups defined by lymph node status [133]. MoureauZabotto et al. suggested that combination of DNA ploidy and SPF predict patients out-come particular in LN-breast cancer patients [134]. DNA ploidy results can be combined with other features in efficient evaluation of prognosis [135].

\section{Nuclear morphometry}

Baak and his coworkers (1985) were among the pioneers in introducing morphometry for prognostication of breast cancer [62]. They found that morphologic features are associated with high risk in pre-invasive breast cancer. The independent prognostic value of nuclear variables was established in several studies on infiltrating breast cancer [136]. Nuclear area and diameter were shown to be useful prognostic factors. However, nuclear diameter has failed to separate the primary tumor from its metastasis [137]. Patients with high nuclear area values and high SD of nuclear area values tend to have poor prognosis [138]. High mean nuclear area is related to poor histological grade [139]. Evaluation of nuclear area can be used for morphometric grading of breast cancer [140]. The latter study also showed that the nuclear area was a significant prognosticator among $\mathrm{LN}+$ and all patients, but completely lacked significance among LN-patients. 


\section{Adhesion molecules E-cadherin}

Cell adhesion molecules play an important role in the maintenance of tissue architecture [141]. E-cadherin is a member of a family of transmembrane glycoproteins that mediate homotypic calcium dependent cell-to-cell adhesion in epithelial tissues [142]. Loss of normal function of E-cadherin is known to promote cancer invasion in several human cancers [143]. Several studies have demonstrated that reduced E-cadherin expression is an indicator of increased invasiveness and dedifferentiation in breast cancer $[144,145]$. A recent study found that the expression of E-cadherin correlates with histological type and grade [146]. The expression of E-cadherin in infiltrative lobular carcinoma was completely negative or weakly positive whereas infiltrating ductal carcinoma showed greater immunoreactivity in grade 1 breast carcinoma than in grade 2 and grade 3 carcinomas [147]. There was an inverse relationship between E-cadherin expression and axillary lymph node involvement. Reduction in E-cadherin expression was associated with the involvement of the axillary lymph nodes [148]. Gamallo and his associates [149], and Lipponen and his co-worders [142] did not agree with this finding. Siitonen et al. [144] showed that reduced E-cadherin expression was independently associated with shorter disease free survival. Other authors stated that the prognostic value of E-cadherin was stronger among patients with $\mathrm{LN}+$ breast cancer $[150,151]$ than among all patients. However, there was no significant association with prognosis among LN- patients [150]. The latter findings can explain the variable findings by different research groups on the prognostic significance of E-cadherin among all breast cancer patients.

\section{Catenins}

Intracellular proteins ( $\alpha-\beta$ - $\gamma$-catenins), are associated with E-cadherin's cytoplasmic tail and link actin to the microfilament network of the cellular cytoskeleton. This binding is essential for the adhesive function of E-cadherin [152]. Alterations in expression of catenins may lead to the disassembly of cadherin junctions and to the generation of more invasive cells [153]. Many studies have suggested that loss of E-cadherin and catenin expression may be associated with poor prognosis of breast cancer $[154,155]$. We did not find any reports of catenins associated with prognostic data which is related to the lymph node status.

\section{44}

CD44 is a family of cell surface transmembrane glycoproteins which is expressed in a wide variety of tissues and cell types $[156,157]$. In human breast cancer, the prognostic value of the various isoforms has not been recognized as independent predictors of breast cancer outcome $[158,159]$. Foekens and co-workers [156] stated that the expression of exon v6 of CD44 may be a marker for identifying patients with relatively favourable prognosis among LN- patients.

\section{Extracellular matrix}

Tenascin

Tenascin is a glycoprotein of the extracellular matrix and appears in the stroma of benign and malignant tumors [160]. Many studies have stated that loss of tenascin expression in breast cancer cells appears to indicate poor prognosis $[161,162]$. So far we do not have knowledge of differences in the prognostic value between $\mathrm{LN}+$ and $\mathrm{LN}$ - patients.

\section{Matrix metalloproteinases (MMPs)}

MMPs are a family of proteinases that play an important role in malignant tumor growth, invasion, metastasis and angiogenesis [163,164]. High expression levels of MMPs in tumor tissue are usually associated with poor survival [165]. In breast cancer, Talvensaari-Mattila and his coworker [166] demonstrated that overexpression of MMP-2 is associated with poor prognosis. Prognostic data on $\mathrm{LN}$ + and LN - patients are not available.

\section{Cystatin A}

Cystatin A is a natural cysteine proteinase inhibitor and is found in a wide variety of normal cells. The physiologic role of Cystatin A is not fully known, however. Cystatin A is present in large amounts in follicular dendritic cells in lymphoid tissues [167]. In malignant tissues, cystatin A has been found in many tumors including breast cancer [168]. In breast cancer patients, Kuopio et al. (1998) demonstrated that the expression of cystatin A was associated with poor outcome; the study also showed that cystatin A was a prognostic marker for $\mathrm{LN}$ - patients. In $\mathrm{LN}+$ patients, cystatin A was without significance [34].

\section{Grading}

Various histological grading systems of breast carcinoma have been described [169-171]. The majority of tumor grading systems combine nuclear grade, tubular formation and mitotic rate. In Europe, Elston and Ellis (1991) stressed the importance of careful grading [172] and corresponding approach has become increasingly popular in the US $[173,68]$. It was suggested that the histological grade functions best as a prognosticator in LN- patients for making decision when tumor sizes fall between tumor size categories [174]. The applied histological features can be measured morphometrically $[71,140,175]$, making the grading system robust and reproducible. The multivariate grading methods $[62,176-178]$ are comparable or better than grading methods alone and can be expected to be more reproducible. However, the performance in grouping of the patients in low and high grade categories is not necessarily identical because these grading methods were 
originally based on different patient materials [179]. It is important to notice that most multivariate methods include lymph node status as a contributing feature and for that reason multivariate methods or indices are applicable to both $\mathrm{LN}+$ and $\mathrm{LN}$ - patients. This also applies to the Nottingham prognostic index which combines tumor size, lymph node status, and histological grade [172]. So far, however, there are few studies comparing traditional and multivariate grading in clinical practice or in different patient groups in terms of power to finding patients with bad prognosis. But we know that different individual prognostic factors and grading systems often give parallel results. For example: when DNA ploidy status is diploid, histological grade is generally low, and when DNA ploidy is aneuploid, histological grade is higher [180]. If histological grade is used as the basic classifier of patients into treatment groups, DNA ploidy can be used as a method to confirm the classification especially in situations of uncertainty. In the same way, other biological prognosticators can and probably should be applied in clinical practice.

\section{Conclusion}

Mitotic activity indices (SMI or MAI) are the most powerful general prognostic markers and highly associated with survival in LN+ patients and in LN- patients younger than 55 years old.

E-cadherin was the second most important prognostic marker in patients with $\mathrm{LN}+$, followed by HER2/neu. In LN- patients, cathepsin D was the second most important prognostic marker followed by HER2/neu, SPF, and aneuploidy.

Table 1 lists histological prognostic markers in LN- and $\mathrm{LN}+$ breast cancers. Because the presented survival associated significances are based on different studies, they are not directly comparable. However, reliable comparison in term of prognostic value can be done after univariate analysis in the same group of patients. Multivariate analysis is less suitable for comparison of variables because the goal of the multivariate analysis is the removal of the prognostic overlaps. The strength of association can be evaluated either by risk ratio, relative risk, or comparison of the survival curves defined by 2 cutpoint associated patient groups in respect to disease free survival (DFS), overall survival (OS), or disease specific survival (DSS). The difference in the importance of prognosticators is presented in Table 2. Generally, comparison is made difficult by the lack of standardized study protocols. Table 2 shows, however, that prognosticators vary in terms of stage: the survival of LN- and LN+ patients can best be predicted with prognosticators specific to the LN status.

We conclude that studies on prognostic evaluation of new potential markers in breast cancer should not be under-
Table 2: Comparison of different prognosticators in single studies on breast cancer.

\begin{tabular}{|c|c|c|}
\hline LN + & Prognosticator & $P$ value \\
\hline \multicolumn{3}{|c|}{ Kuopio et al. 1998 [34] } \\
\hline & I. Bcl-2 & 0.017 \\
\hline & 2. p53 & 0.121 \\
\hline & 3. Cystatin A & 0.386 \\
\hline \multicolumn{3}{|c|}{ Jalava et al. 2002 [16] } \\
\hline & I. ErbB2 & 0.0002 \\
\hline & 2. SMI & 0.0014 \\
\hline & 3. $\mathrm{Bcl}-2$ & 0.048 \\
\hline \multicolumn{3}{|c|}{ Elzagheid et al. 2002 [150] } \\
\hline & I. E-cadherin & 0.0006 \\
\hline & 2. SMI & 0.0133 \\
\hline \multicolumn{3}{|l|}{ LN - } \\
\hline \multicolumn{3}{|c|}{ Kuopio et al. 1998 [34] } \\
\hline & I. Cystatin A & 0.010 \\
\hline & 2. p53 & 0.021 \\
\hline & 3. $\mathrm{Bcl}-2$ & 0.874 \\
\hline \multicolumn{3}{|c|}{ Jalava et al. 2002 [16] } \\
\hline & I. SMI & 0.0001 \\
\hline & 2. ErbB2 & N.S. \\
\hline & 3. $\mathrm{Bcl}-2$ & N.S. \\
\hline \multicolumn{3}{|c|}{ Elzagheid et al. 2002 [150] } \\
\hline & I. SMI & 0.0299 \\
\hline & 2. E-cadherin & $0.558 I$ \\
\hline
\end{tabular}

$P$ values refer to the results of univariate analysis. Comparison of univariate analyses in a study allows one to conclude on the relative strengths of different prognosticators.

taken without studying the prognosis among all patients, and separately among $\mathrm{LN}+$ and $\mathrm{LN}$ - patients. Correspondingly the use of prognosticators for clinical decision making should be based on the gathered knowledge of differences between $\mathrm{LN}+$ and $\mathrm{LN}$ - patients.

\section{Acknowledgements}

This work was supported by Cancer Society of South-West Finland, Turku, and by special government Funding (EVO) allocated to Turku University Central Hospital.

\section{References}

I. Smigal C, Jemal A, Ward E, Cokkinides V, Smith R, Howe HL, Thun $M$ : Trends in breast cancer by race and ethnicity: update 2006. CA A Cancer J Clin 2006, 56:168-I83.

2. Finnish Cancer Registry: Cancer in Finland. 2002 and 2003. Cancer statistics of the National Research and Development Centre for Welfare and Health. Cancer Society of Finland. Publication No. 66, Helsinki 2005. ISSN 0585-9603

3. Levi F, Lucchini F, Negri E, La Vecchia C: Worldwide patterns of cancer mortality, 1990-1994. Eur J Cancer Prev 1999, 8(5):38I-400.

4. Fisher ER, Anderson S, Redmond C, Fisher B: Pathologic findings from the National Surgical adjuvant breast project protocol B-06. 10-year pathologic and clinical prognostic discriminants. Cancer I993, 7 I(8):2507-14.

5. Goldhirsch A, Wood WC, Gelber RD, Coates AS, Thurlimann B, Senn HJ: Meeting highlights: updated international expert consensus on the primary therapy of early breast cancer. Clin Oncol 2003, 21 (17):3357-65. 
6. Ali SM, Leitzel K, Chinchilli VM, Engle L, Demers L, Harvey HA, Carney W, Allard JW, Lipton : Relationship of serum HER-2/neu and serum CA 15-3 in patients with metastatic breast cancer. Clin Chem 2002:13 |4-20.

7. King CR, Kraus MH, Aaronson SA: Amplification of a novel verbB-related gene in a human mammary carcinoma. Science 1985, 229(47| 7):974-6.

8. Tal M, Wetzler M, Josefberg Z, Deutch A, Gutman M, Assaf D, Kris R, Shiloh Y, Givol D, Schlessinger J: Sporadic amplification of the HER2/neu protooncogene in adenocarcinomas of various tissues. Cancer Res 1988, 48(6): 15 I7-20.

9. Devilee P, Schuuring E, van de Vijver MJ, Cornelisse C): Recent developments in the mol ecular genetic understanding of breast cancer. Crit Rev Oncog 1994, 5(2-3):247-70.

10. Ravdin PM, Chamness GC: The c-erbB-2 proto-oncogene as a prognostic and predictive marker in breast cancer: a paradigm for the development of other macromolecular markers. Gene 1995, I 59(I): 19-27.

II. Naidu R, Yadav M, Nair S, Kutty MK: Expression of c-erbB3 protein in primary breast carcinomas. $\mathrm{Br} /$ Cancer 1998, 78(10): $1385-90$

12. Yeh IT: Measuring HER-2 in breast cancer. Immunohistochemistry, FISH, or ELISA? Am J Clin Pathol 2002, I I 7(Suppl):S26-35. Review

13. Winters ZE, Leek RD, Bradburn MJ, Norbury CJ, Harris AL: Cytoplasmic p2IWAFI/CIPI expression is correlated with HER$2 /$ neu in breast cancer and is an independent predictor of prognosis. Breast Cancer Res 2003, 5(6):R242-9.

14. Gu M, Ghafari S, Zhao M: Fluorescence in situ hybridization for HER-2/neu amplification of breast carcinoma in archival fine needle aspiration biopsy specimens. Acta Cytol 2005, 49(5):47I-6.

15. Slamon DJ, Clark GM, Wong SG, Levin WJ, Ullrich A, McGuire WL: Human breast cancer: correlation of relapse and survival with amplification of the HER-2/neu oncogene. Science 1987 235(4785): 177-82.

16. Jalava PJ, Kuopio T, Kortelainen S, Kronqvist P, Collan YU: Quantitation of erbB2 positivity for evaluation of high-risk patients. Ann Med 2002, 34(7-8):544-53.

17. Press MF, Bernstein L, Thomas PA, Meisner LF, Zhou JY, Ma Y, Hung G, Robinson RA, Harris C, El-Naggar A, Slamon DJ, Phillips RN, Ross JS, Wolman SR, Flom KJ: HER-2/neu gene amplification characterized by fluorescence in situ hybridization: poor prognosis in node-negative breast carcinomas. J Clin Oncol 1997, I 5(8):2894-904.

18. Tawfik OW, Kimler BF, Davis M, Donahue JK, Persons DL, Fan F, Hagemeister S, Thomas P, Connor C, Jewell W, Fabian C): Comparison of immunohistochemistry by automated cellular imaging system (ACIS) versus fluorescence in-situ hybridization in the evaluation of HER-2/neu expression in primary breast carcinoma. Histopathology 2006, 48(3):258-67.

19. Isola J, Tanner M, Forsyth A, Cooke TG, Watters AD, Bartlett JM: Interlaboratory comparison of HER-2 oncogene amplification as detected by chromogenic and fluorescence in situ hybridization. Clin Cancer Res 2004, I ( (14):4793-8.

20. Seidman AD, Fornier MN, Esteva FJ, Tan L, Kaptain S, Bach A, Panageas KS, Arroyo C, Valero V, Currie V, Gilewski T, Theodoulou M, Moynahan ME, Moasser M, Sklarin N, Dickler M, D'Andrea G, Cristofanilli M, Rivera E, Hortobagyi GN, Norton L, Hudis CA: Weekly trastuzumab and paclitaxel therapy for metastatic breast cancer with analysis of efficacy by HER2 immunophenotype and gene amplification. J Clin Oncol 200I, I 9( I 0):2587-95.

21. Joensuu $H$, Kellokumpu-Lehtinen PL, Bono P, Alanko T, Kataja V, Asola R, Utriainen T, Kokko R, Hemminki A, Tarkkanen M, Turpeenniemi-Hujanen T, Jyrkkio S, Flander M, Helle L, Ingalsuo S, Johansson $K$, Jaaskelainen AS, Pajunen M, Rauhala M, Kaleva-Kerola J, Salminen T, Leinonen M, Elomaa I, Isola J, FinHer Study Investigators: Adjuvant docetaxel or vinorelbine with or without trastuzumab for breast cancer. N Engl J Med 2006, 354(8):809-20.

22. Piccart-Gebhart MJ, Procter M, Leyland-Jones B, Goldhirsch A, Untch M, Smith I, Gianni L, Baselga J, Bell R, Jackisch C, Cameron D, Dowsett M, Barrios CH, Steger G, Huang CS, Andersson M, Inbar M, Lichinitser M, Lang I, Nitz U, Iwata H, Thomssen C, Lohrisch C, Suter TM, Ruschoff J, Suto T, Greatorex V, Ward C, Straehle C, McFadden E, Dolci MS, Gelber RD, Herceptin Adjuvant (HERA) Trial Study
Team: Trastuzumab after adjuvant chemotherapy in HER2positive breast cancer. N Engl J Med 2005, 353(16): 1659-72.

23. Romond EH, Perez EA, Bryant J, Suman VJ, Geyer CE Jr, Davidson NE, Tan-Chiu E, Martino S, Paik S, Kaufman PA, Swain SM, Pisansky TM, Fehrenbacher L, Kutteh LA, Vogel VG, Visscher DW, Yothers G, Jenkins RB, Brown AM, Dakhil SR, Mamounas EP, Lingle WL, Klein PM, Ingle JN, Wolmark N: Trastuzumab plus adjuvant chemotherapy for operable HER2-positive breast cancer. $N$ Engl J Med 2005, 353(16): 1673-84.

24. Levine AJ, Momand J, Finlay CA: The p53 tumour suppressor gene. Nature 199I, 35 I (6326):453-6

25. Kastan MB, Onyekwere O, Sidransky D, Vogelstein B, Craig RW Participation of $\mathrm{p} 53$ protein in the cellular response to DNA damage. Cancer Res I99I, 5 I(23 Pt I):6304-II.

26. Barnes DM, Camplejohn RS: P53, apoptosis, and breast cancer. J Mammary Gland Biol Neoplasia 1996, I (2): 163-75.

27. Hollstein M, Sidransky D, Vogelstein B, Harris CC: p53 mutations in human cancers. Science I99|, 253(50 I 5):49-53.

28. Bookstein R, MacGrogan D, Hilsenbeck SG, Sharkey F, Allred DC: p53 is mutated in a subset of advanced-stage prostate cancers. Cancer Res 1993, 53(14):3369-73.

29. Temmim L, Baker H, Sinowatz F: Immunohistochemical detection of p53 protein expression in breast cancer in young Kuwaiti women. Anticancer Res 200I, 2 I(IB):743-8.

30. Bergh J: Clinical studies of p53 in treatment and benefit of breast cancer patients. Endocr Relat Cancer 1999, 6(I):5I-9.

3I. Kalogeraki A, Panayiotides J, Tamiolakis D, Tzardi M, Chaniotis V, Chalkiadakis G, Melissas J, Stiftsis D, Kanavaros P, Delides GS: P53 expression in patients with malignant and benign breast diseases. Anticancer Res 2000, 20(3A): I $801-5$.

32. Metcalfe S, Wheeler TK, Picken S, Negus S, Jo Milner A: P53 autoantibodies in 1006 patients followed up for breast cancer. Breast Cancer Res 2000, 2(6):438-43.

33. Allred DC, Clark GM, Elledge R, Fuqua SA, Brown RW, Chamness GC, Osborne CK, McGuire WL: Association of p53 protein expression with tumor cell proliferation rate and clinical outcome in node-negative breast cancer. I Natl Cancer Inst 1993, 85(3):200-6.

34. Kuopio $T$, Kankaanranta $A$, Jalava $P$, Kronqvist $P$, Kotkansalo $T$, Weber E, Collan Y: Cysteine proteinase inhibitor cystatin A in breast cancer. Cancer Res 1998, 58(3):432-6.

35. Gohring UJ, Bersch A, Becker M, Neuhaus W, Schondorf $T$ : p2 I (waf) correlates with DNA replication but not with prognosis in invasive breast cancer. J Clin Pathol 200 I, 54(I I ):866-70.

36. Elledge RM, Allred DC: Prognostic and predictive value of p53 and P2I in breast cancer. Breast Cancer Res Treat 1998, 52(13):79-98.

37. Thor AD, Liu S, Moore DH 2nd, Shi Q, Edgerton SM: p(2 IWAFI/ CIPI) expression in breast cancers: associations with p53 and outcome. Breast Cancer Res Treat 2000, 6 I (I):33-43.

38. Wiesmuller L, Wittinghofer F: Signal transduction pathways involving Ras. Cell Signal 1994, 6(3):247-67.

39. Medema RH, Bos JL: The role of $\mathrm{p2} I$ ras in receptor tyrosine kinase signaling. Crit Rev Oncog 1993, 4(6):6|5-61.

40. Gulbis B, Galand P: Immunodetection of the $\mathrm{p} 2 \mathrm{I}$-ras products in human normal and preneoplastic tissues and solid tumors. Hum Pathol 1993, 24(1 2): I27|-85.

41. Rundle A, Tang D, Brandt-Rauf P, Zhou J, Kelly A, Schnabel F, Perera FP: Association between the ras p2I oncoprotein in blood samples and breast cancer. Cancer Lett 2002, 185(I):7I-8.

42. Czerniak B, Chen R, Tuziak T, Markiewski M, Kram A, Gorczyca W, Deitch D, Herz F, Koss LG: Expression of ras oncogene p2 I protein in relation to regional spread of human breast carcinomas. Cancer 1989, 63(10):2008-13.

43. Barbareschi M: p27 Expression, a cyclin dependent kinase inhibitor in breast carcinoma. Adv Clin Path 1999, 3(4): I | 9-27.

44. Chiarle R, Pagano M, Inghirami G: The cyclin dependent kinase inhibitor p27 and its prognostic role in breast cancer. Breast Cancer Res 200I, 3(2):91-4.

45. Tsuchiya A, Zhang G], Kanno M: Prognostic impact of cyclindependent kinase inhibitor p27kip 1 in node-positive breast cancer. J Surg Oncol 1999, 70(4):230-4.

46. Chappuis PO, Kapusta L, Begin LR, Wong N, Brunet JS, Narod SA Slingerland J, Foulkes WD: Germline BRCAI/2 mutations and p27(Kipl) protein levels independently predict outcome after breast cancer. J Clin Oncol 2000, 18(24):4045-52. 
47. Foulkes WD, Brunet JS, Stefansson IM, Straume O, Chappuis PO, Begin LR, Hamel N, Goffin JR, Wong N, Trudel M, Kapusta L, Porter $P$, Akslen LA: The prognostic implication of the basal-like (cyclin E high/p27 low/p53+/glomeruloid-microvascular-proliferation+) phenotype of BRCAI-related breast cancer. Cancer Res 2004, 64(3):830-5.

48. Berns EM, Klijn JG, van Putten WL, van Staveren IL, Portengen $H$ Foekens JA: c-myc amplification is a better prognostic factor than HER2/neu amplification in primary breast cancer. Cancer Res 1992, 52(5): I 107-13.

49. Naidu R, Wahab NA, Yadav M, Kutty MK: Protein expression and molecular analysis of c-myc gene in primary breast carcinomas using immunohistochemistry and differential polymerase chain reaction. Int J Mol Med 2002, 9(2): 189-96.

50. Aulmann S, Bentz M, Sinn HP: C-myc oncogene amplification in ductal carcinoma in situ of the breast. Breast Cancer Res Treat 2002, 74(I):25-3I.

5I. Silvestrini R, Veneroni S, Daidone MG, Benini E, Boracchi P, Mezzetti M, Di Fronzo G, Rilke F, Veronesi U: The Bcl-2 protein: a prognostic indicator strongly related to p53 protein in lymph node-negative breast cancer patients. J Natl Cancer Inst 1994, 86(7):499-504.

52. Olopade OI, Adeyanju MO, Safa AR, Hagos F, Mick R, Thompson CB Recant WM: Overexpression of BCL-x protein in primary breast cancer is associated with high tumor grade and nodal metastases. Cancer I Sci Am 1997, 3(4):230-7.

53. Knowlton K, Mancini M, Creason S, Morales C, Hockenbery D, Anderson BO: Bcl-2 slows in vitro breast cancer growth despite its antiapoptotic effect. J Surg Res 1998, 76(I):22-6

54. Park $\mathrm{SH}$, Kim H, Song BJ: Down regulation of bcl2 expression in invasive ductal carcinomas is both estrogen-and progesterone-receptor dependent and associated with poor prognostic factors. Pathol Oncol Res 2002, 8(I):26-30.

55. Hellemans $P$, van Dam PA, Weyler J, van Oosterom AT, Buytaert $P$, Van Marck E: Prognostic value of bcl-2 expression in invasive breast cancer. Br J Cancer 1995, 72(2):354-60.

56. Bhatavdekar JM, Patel DD, Shah NG, Vora HH, Suthar TP, Chikhlikar PR, Ghosh N, Trivedi TI: Prognostic significance of immunohistochemically localized biomarkers in stage II and stage III breast cancer: a multivariate analysis. Ann Surg Oncol 2000 7(4):305-II.

57. Jalava PJ, Collan YU, Kuopio T, Juntti-Patinen L, Kronqvist P: Bcl-2 immunostaining: a way to finding unresponsive postmenopausal N+ breast cancer patients. Anticancer Res 2000 20(2B): $1213-9$

58. Laroye GJ, Minkin S: The impact of mitotic index on predicting outcome in breast carcinoma: a comparison of different counting methods in patients with different lymph node status. Mod Pathol 1991, 4(4):456-60.

59. Aaltomaa S, Lipponen P, Eskelinen M, Kosma VM, Marin S, Alhava E, Syrjanen K: Mitotic indexes as prognostic predictors in female breast cancer. J Cancer Res Clin Oncol 1992, I I 8:75-8I.

60. Haapasalo H, Pesonen E, Collan Y: Volume corrected mitotic index (M/V-INDEX). The standard of mitotic activity in neoplasms. Pathol Res Pract 1989, I 85:55 I-4.

61. Kujari HP, Collan YU, Atkin NB: Use of the mitotic counts for the prognosis and grading of breast cancer. Method evaluation study. Pathol Res Pract 1994, I 90(6):593-9.

62. Baak JP, Van Dop H, Kurver PH, Hermans J: The value of mor phometry to classic prognosticators in breast cancer. Cancer 1985, 56(2):374-82

63. Lipponen P, Papinaho S, Eskelinen M, Klemi PJ, Aaltomaa S, Kosma VM, Marin S, Syrjanen K: DNA ploidy, S-phase fraction and mitotic indices as prognostic predictors of female breast cancer. Anticancer Res 1992, 12:1533-8.

64. Collan YU, Kuopio T, Baak JP, Becker R, Bogomoletz WV, Deverell $M$, van Diest $P$, van Galen C, Gilchrist K, Javed A, Kosma VM, Kujari H, Luzi P, Mariuzzi GM, Matze E, Montironi R, Scarpelli M, Sierra D, Sisti S, Toikkanen S, Tosi P, Whimster WF, Wisse E: Standardized mitotic counts in breast cancer. Evaluation of the method. Pathol Res Pract 1996, I92(9):931-41.

65. Ikpatt OF, Kuopio T, Collan Y: Proliferation in African breast cancer: biology and prognostication in Nigerian breast cancer material. Mod Pathol 2002, I 5(8):783-9.
66. Groenendijk RP, Bult P, Noppen CM, Boetes C, Ruers T], Wobbes T: Mitotic activity index in interval breast cancers. Eur J Surg Oncol 2003, 29(I):29-3I.

67. Lipponen PK, Collan Y, Eskelinen MJ: Volume corrected mitotic index (M/V index), mitotic activity index (MAI), and histological grading in breast cancer. Int Surg 1991, 76:245-9.

68. Simpson JF, Gray R, Dressler LG, Cobau CD, Falkson Cl, Gilchrist KW, Pandya KJ, Page DL, Robert NJ: Prognostic value of histologic grade and proliferative activity in axillary node-positive breast cancer: results from the Eastern Cooperative Oncology Group Companion Study, EST 4189. J Clin Oncol 2000, I 8( I 0):2059-69.

69. Baak JP, van Diest PJ, Voorhorst FJ, van der Wall E, Beex LV, Vermorken JB, Janssen EA: Prospective multicenter validation of the independent prognostic value of the mitotic activity index in lymph node-negative breast cancer patients younger than 55 years. J Clin Oncol 2005, 23(25):5993-600 I.

70. Baak JP, Colpaert CG, van Diest PJ, Janssen E, van Diermen B, Albernaz E, Vermeulen PB, Van Marck EA: Multivariate prognostic evaluation of the mitotic activity index and fibrotic focus in node-negative invasive breast cancers. Eur J Cancer 2005, 4 I ( I 4):2093-10 I

7I. Kronqvist P, Kuopio T, Collan Y: Morphometric grading in breast cancer: thresholds for mitotic counts. Hum Pathol 1998: 1462-8.

72. Gerdes J, Schwab U, Lemke H, Stein H: Production of a mouse monoclonal antibody reactive with a human nuclear antigen associated with cell proliferation. Int J Cancer I 983, 3 I (I): I 3-20.

73. Cooper LS, Gillett CE, Smith P, Fentiman IS, Barnes DM: Cell proliferation measured by MIBI and timing of surgery for breast cancer. Br J Cancer I998, 77(9): |502-7.

74. Gerdes J, Lemke H, Baisch H, Wacker HH, Schwab U, Stein H: Cell cycle analysis of a cell proliferation- associated human nuclear antigen defined by the monoclonal antibody Ki-67. J Immunol 1984, I33(4): I710-5

75. Gerdes J, Li L, Schlueter C, Duchrow M, Wohlenberg C, Gerlach C, Stahmer I, Kloth S, Brandt E, Flad HD: Immunobiochemical and molecular biologic characterization of the cell proliferationassociated nuclear antigen that is defined by monoclonal antibody Ki-67. Am J Pathol I99I, I38(4):867-73.

76. Isola JJ, Helin HJ, Helle MJ, Kallioniemi OP: Evaluation of cell proliferation in breast carcinoma. Comparison of Ki-67 immunohistochemical study, DNA flow cytometric analysis, and mitotic count. Cancer 1990, 65(5): I I 80-4.

77. Railo M, Nordling S, von Boguslawsky K, Leivonen M, Kyllonen L, von Smitten K: Prognostic value of Ki-67 immunolabelling in primary operable breast cancer. Br J Cancer 1993, 8(3):579-83.

78. Pietilainen T, Lipponen P, Aaltomaa S, Eskelinen M, Kosma VM, Syrjanen $\mathrm{K}$ : The important prognostic value of $\mathrm{Ki}-67$ expression as determined by image analysis in breast cancer. J Cancer Res Clin Oncol 1996, I 22( I I):687-92.

79. Jalava PJ, Kuopio T, Juntti-Patinen L, Kotkansalo T, Kronqvist P, Collan YU: Ki-67 immunohistochemistry: A valuable marker in prognostication but also a risk of misclassification. Proliferation subgroups based on $\mathrm{Ki}-67$ fraction and standardized mitotic index. Histopathology 2006, 48:674-682.

80. Santamaria L, Martin R, Gomez V, Ingelmo I, Lopez C, Revestido R: Stereologic estimation of Ki-67, caspase3, and GSTP I positive cells in prostate lesions. Image Analysis Stereol 2005, 24:77-84.

8I. Linden MD, Torres FX, Kubus J, Zarbo RJ: Clinical application of morphologic and immunocytochemical assessments of cell proliferation. Am J Clin Pathol I 992, 97(5 SuppI I):S4-I3

82. Kesari AL, Chellam VG, Nair PP, Madhavan J, Nair P, Nair MK, Pilla MR: Tumor proliferative fraction in infiltrating duct carcinoma. Gen Diagn Pathol 1997, I43(4):219-24.

83. Jeziorski $A$, Blonski JZ, Niewiadomska $H$ : The expression of products of oncogens C-erbB2 and EGFR and proliferating antigens Ki67 and PCNA in primary invasive ductal cancer of female breast. J Exp Clin Cancer Res 2000, I 9(I):6I-7.

84. Aaltomaa S, Lipponen P, Syrjanen K: Proliferating cell nuclear antigen (PCNA) immunolabeling as a prognostic factor in axillary lymph node negative breast cancer. Anticancer Res 1993, I3(2):533-8

85. Mourad WA, Erkman-Balis B, Livingston S, Shoukri M, Cox CE, Nicosia SV, Rowlands DT Jr: Argyrophilic nucleolar organizer 
regions in breast carcinoma. Correlation with DNA flow cytometry, histopathology, and lymph node status. Cancer 1992, 69(7): 1739-44.

86. Dasgupta A, Ghosh RN, Sarkar R, Laha RN, Ghosh TK, Mukherjee C: Argyrophilic nucleolar organiser regions (AgNORs) in breast lesions. J Indian Med Assoc 1997, 95(9):492-4.

87. Aubele M, Auer G, Jutting U, Falkmer U, Gais P: Prognostic value of quantitatively measured AgNORs in ductal mammary carcinoma. Anal Quant Cytol Histol 1994:2 I I-8.

88. Rzymowska J: AgNOR counts and their combination with flow cytometric analyses and clinical parameters as a prognostic indicator in breast carcinoma. Tumori 1997, 83(6):938-42.

89. Biesterfeld S, Farokhzad F, Kluppel D, Schneider S, Hufnagl P: Improvement of breast cancer prognostication using cell kinetic-based silver-stainable nucleolar organizer region quantification of the MIB-I positive tumor cell compartment. Virchows Arch 200I, 438(5):478-84

90. Derenzini M, Ceccarelli C, Santini D, Taffurelli M, Trere D: The prognostic value of the AgNOR parameter in human breast cancer depends on the pRb and p53 status. J Clin Pathol 2004, 57(7):755-6I.

91. Toikkanen S, Joensuu H: AgNOR counts have no prognostic value in breast cancer. J Pathol 1993, I69(2):25।-4

92. Simha M, Menon M, Doctor V: Prognostic value of argyrophylic nucleolar organiser regions (AgNORs) in breast lesions. Indian I Cancer 1996, 33(2):76-85.

93. Ferno M, Baldetorp B, Borg A, Olsson H, Sigurdsson H, Killander D: Flow cytometric DNA index and S-phase fraction in breast cancer in relation to other prognostic variables and to clinical outcome. Acta Oncol 1992, 3 I(2): 157-65.

94. Michels J], Duigou F, Marnay J: Flow cytometry in primary breast carcinomas. Prognostic impact of proliferative activity. Breast Cancer Res Treat 2000, 62(2): I 17-26.

95. Fietkau R, Iro H, Tulusan AH, Dressel V, Altendorf-Hofmann A, Sauer $R$ : Prognostic value of S-phase fraction in head and neck squamous cell carcinomas and nodal negative breast carcinomas. Strahlenther Onkol 1994, I 70(I): | 3-24.

96. Zhang S, Yuan Y, Wang X: [Prognosis prediction of S-phase fraction and p53, c-erbB-2, estrogen receptor, progesterone receptor in axillary node-negative breast cancer]. Zhonghua Wai Ke Za Zhi 1997, 35(8):475-7.

97. Jones S, Clark G, Koleszar S, Ethington G, Mennel R, Paulson S, Brooks B, Kerr R, Denham C, Savin M, White C, Blum J, Kirby R, Stone M, Pippen J, Kitchens L, George T, Cooper B, Peters G, Knox S, Grant M, Cheek H, Jones R, Kuhn J, Lieberman Z, Savino D, Rietz $C$ : Low proliferative rate of invasive node-negative breast cancer predicts for a favorable outcome: a prospective evaluation of 669 patients. Clin Breast Cancer 200I, I(4):3I 0-4

98. Collan Y, Klemi P, Kallioniemi OP, Joensuu H, Nordling S, Eskelinen $M$ : Significance of variation in DNA flow cytometric analyses from paraffin-embedded breast cancers. Evaluation of the grading efficiency of ploidy determination, DNA index, and S-phase fraction. Pathol Res Pract 1992, 188(4-5):58I-6.

99. Greco S, Marsigliante S, Leo G, Storelli C: Co-expression of thymidine kinase and cathepsin $D$ in 200 primary breast carcinomas. Cancer Lett 2000, 160(I):13-9.

100. Isola J, Weitz S, Visakorpi T, Holli K, Shea R, Khabbaz N, Kallioniemi OP: Cathepsin $D$ expression detected by immunohistochemistry has independent prognostic value in axillary node-negative breast cancer. J Clin Oncol I 993, I I ( I):36-43.

10I. Billgren AM, Rutqvist LE, Johansson H, Hagerstrom T, Skoog L: The role of cathepsin $D$ and PAI- $I$ in primary invasive breast cancer as prognosticators and predictors of treatment benefit with adjuvant tamoxifen. Eur / Cancer 2000, 36(II): 1374-80.

102. Rochefort $\mathrm{H}$ : Estrogens, cathepsin $\mathbf{D}$ and metastasis in cancers of the breast and ovary: invasion or proliferation? $C R$ Seances Soc Biol Fil 1998, 192(2):24I-5I.

103. Aaltonen M, Lipponen P, Kosma VM, Aaltomaa S, Syrjanen K: Prognostic value of cathepsin- $D$ expression in female breast cancer. Anticancer Res 1995, 15(3): 1033-7.

104. Ramirez-Ortega MC, Frias-Mendivil M, Delgado-Chavez R, MenesesGarcia A, Carrillo-Hernandez JF, Ramirez-Ugalde MT, ZeichnerGancz I: Expression of cathepsin D in breast cancer and its clinical and histopathological correlations. Rev Invest Clin 1997, 49(5):36I-8.
105. Lippman ME, Dickson RB, Gelmann EP, Rosen N, Knabbe C, Bates S, Bronzert D, Huff K, Kasid A: Growth regulation of human breast carcinoma occurs through regulated growth factor secretion. J Cell Biochem I987, 35(I):I-16.

106. Umekita Y, Ohi Y, Sagara Y, Yoshida H: Co-expression of epidermal growth factor receptor and transforming growth factoralpha predicts worse prognosis in breast-cancer patients. Int J Cancer 2000, 89(6):484-7.

107. Kumar RR, Meenakshi A, Sivakumar N: Enzyme immunoassay of human epidermal growth factor receptor (hEGFR). Hum Antibodies 200।, 10(3-4): 143-7.

108. Aziz SA, Pervez S, Khan S, Kayani N, Rahbar MH: Epidermal growth factor receptor (EGFR) as a prognostic marker: an immunohistochemical study on 315 consecutive breast carcinoma patients. J Pak Med Assoc 2002, 52(3): 104-10.

109. Rampaul RS, Pinder SE, Wencyk PM, Nicholson RI, Blamey RW, Robertson JF, Ellis IO: Epidermal growth factor receptor status in operable invasive breast cancer: is it of any prognostic value? Clin Cancer Res 2004, 10(7):2578

II0. Tsutsui S, Ohno S, Murakami S, Hachitanda Y, Oda S: Prognostic value of epidermal growth factor receptor (EGFR) and its relationship to the estrogen receptor status in 1029 patients with breast cancer. Breast Cancer Res Treat 2002, 7 I (I):67-75.

III. Ellis MJ, Jenkins S, Hanfelt J, Redington ME, Taylor M, Leek R, Siddle $\mathrm{K}$, Harris A: Insulin-like growth factors in human breast cancer. Breast Cancer Res Treat 1998, 52(I-3): I75-84.

1 12. Yu H, Levesque MA, Khosravi MJ, Papanastasiou-Diamandi A, Clark GM, Diamandis EP: Associations between insulin-like growth factors and their binding proteins and other prognostic indicators in breast cancer. $\mathrm{Br} J$ Cancer 1996, 74(8): I 242-7.

113. Surmacz E, Guvakova MA, Nolan MK, Nicosia RF, Sciacca L: Type I insulin-like growth factor receptor function in breast cancer. Breast Cancer Res Treat 1998, 47(3):255-67.

114. Eppler E, Zapf J, Bailer N, Falkmer UG, Falkmer S, Reinecke M: IGF$I$ in human breast cancer: low differentiation stage is associated with decreased IGF-I content. Eur J Endocrinol 2002, |46(6):8|3-2|.

II5. Toropainen EM, Lipponen PK, Syrjanen KJ: Expression of insulinlike growth factor II in female breast cancer as related to established prognostic factors and long-term prognosis. Anticancer Res 1995, I5(6B):2669-74.

116. Blanco G, Alavaikko M, Ojala A, Collan Y, Heikkinen M, Hietanen T, Aine R, Taskinen PJ: Estrogen and progesterone receptors in breast cancer: relationships to tumour histopathology and survival of patients. Anticancer Res 1984, 4(6):383-9.

117. Barbareschi M, Doglioni C: [The immunohistochemical detection of steroid hormone receptors in breast cancer: open problems and new perspectives]. Pathologica 2002, 94(3): II5-20.

1 18. DeSombre ER, Kledzik G, Marshall S, Meites J: Estrogen and prolactin receptor concentrations in rat mammary tumors and response to endocrine ablation. Cancer Res 1976, 36(2 Pt I):354-8.

1 19. Silvestrini R, Daidone MG, Luisi A, Boracchi P, Mezzetti M, Di Fronzo G, Andreola S, Salvadori B, Veronesi U: Biologic and clinicopathologic factors as indicators of specific relapse types in nodenegative breast cancer. J Clin Oncol 1995, I3(3):697-704.

120. Talley LI, Grizzle WE, Waterbor JW, Brown D, Weiss H, Frost AR: Hormone receptors and proliferation in breast carcinomas of equivalent histologic grades in pre- and postmenopausal women. Int J Cancer 2002, 98(I): I | 8-27.

121. Nomura Y, Miura S, Koyama H, Enomoto K, Kasumi F, Yamamoto H, Kimura M, Tominaga T, lino H, Morimoto T, Tashiro H: Relative effect of steroid hormone receptors on the prognosis of patients with operable breast cancer. A univariate and multivariate analysis 3089 Japanese patients with breast cancer from the Study Group for the Japanese Breast Cancer Society on Hormone Receptors and Prognosis in Breast Cancer. Cancer 1992, 69(I): 153-64.

122. Abd El-Rehim DM, Pinder SE, Paish CE, Bell JA, Rampaul RS, Blamey RW, Robertson JF, Nicholson RI, Ellis IO: Expression and coexpression of the members of the epidermal growth factor receptor (EGFR) family in invasive breast carcinoma. $\mathrm{Br}$ Cancer 2004, 9 I (8): 1532-42.

123. Jalava P, Kuopio T, Huovinen R, Laine J, Collan Y: Immunohistochemical staining of estrogen and progesterone receptors: 
aspects for evaluating positivity and defining the cutpoints. Anticancer Res 2005, 25(3c):2535-42.

124. Bocking A, Giroud F, Reith A: Consensus report of the European Society for Analytical Cellular Pathology task force on standardization of diagnostic DNA image cytometry. Anal Quant Cytol Histol 1995, I 7(I): I-7.

125. Auer GU, Caspersson TO, Wallgren AS: DNA content and survival in mammary carcinoma. Anal Quant Cytol 1980:161-5.

126. Erhardt K, Auer G: Mammary carcinoma: DNA analysis in areas showing different histological features in the same tumor. Acta Pathol Microbiol Immunol Scand [A] 1986, 94(I):2 I-8.

127. Bocking A, Chatelain R, Biesterfeld S, Noll E, Biesterfeld D, Wohltmann D, Goecke C: DNA grading of malignancy in breast cancer. Prognostic validity, reproducibility and comparison with other classifications. Anal Quant Cytol Histol 1989, II(2):73-80.

128. Friedrich K, Scheithauer J, Dimmer V, Meyer W, Theissig F, Haroske G, Kunze KD: DNA ploidy and chromosomal imbalances in invasive ductal breast cancer. A comparative study of DNA image cytometry and comparative genomic hybridization (CGH). Anal Cell Pathol 2000, 20(2-3):69-82.

129. Tsutsui S, Ohno S, Murakami S, Hachitanda Y, Oda S: Prognostic value of DNA ploidy in 653 Japanese women with node-negative breast cancer. Int I Clin Oncol 200I, 6(4): I77-82.

130. Wong SW, Rangan AM, Bilous AM, Boyages J, Gebski V, Benson EM: The value of S-phase and DNA ploidy analysis as prognostic markers for node-negative breast cancer in the Australian setting. Pathology 1999, 3 I(2):90-4.

131. Bracko M, Us-Krasovec M, Cufer T, Lamovec J, Zidar A, Goehde W: Prognostic significance of DNA ploidy determined by highresolution flow cytometry in breast carcinoma. Anal Quant Cytol Histol 200I, 23(I):56-66.

132. Yuan J, Hennessy C, Corbett IP, Dykin R, Givan AL, Shenton BK, Henry JA, Wright $C$, Lennard TW: Node negative breast cancer: the prognostic value of DNA ploidy for long-term survival. $\mathrm{Br}$ J Surg 1991, 78(7):844-8.

133. Chassevent A, Jourdan ML, Romain S, Descotes F, Colonna M, Martin PM, Bolla M, Spyratos F: S-phase fraction and DNA ploidy in 633 TIT2 breast cancers: a standardized flow cytometric study. Clin Cancer Res 200I, 7(4):909-I7.

134. Moureau-Zabotto L, Bouchet C, Cesari D, Uzan S, Lefranc JP, Antoine M, Genestie C, Deniaud-Alexandre E, Bernaudin JF, Touboul E, Fleury-Feith J: Combined flow cytometry determination of $\mathbf{S}$ phase fraction and DNA ploidy is an independent prognostic factor in node-negative invasive breast carcinoma: analysis of a series of 27 I patients with stage I and II breast cancer. Breast Cancer Res Treat 2005, 9 I (I):6I-71.

135. Collan YU, Eskelinen MJ, Nordling SA, Lipponen P, Pesonen E, Kumpusalo LM, Pajarinen P, Kettunen KO: Prognostic studies in breast cancer. Multivariate combination of nodal status, proliferation index, tumor size, and DNA ploidy. Acta Oncol 1994 33(8):873-8

136. Aaltomaa S, Lipponen P, Papinaho S, Klemi P, Kosma VM, Marin M, Alhava E, Syrjanen K: Nuclear morphometry and DNA flow cytometry as prognostic factors in female breast cancer. Eur J Surg 1992, 3:135-41.

137. Zajdela A, De LaRiva LS, Ghossein NA: The relation of prognosis to the nuclear diameter of breast cancer cells obtained by cytologic aspiration. Acta Cytologica 1979, 23:75-80.

138. Tosi P, Luzi P, Sforza V, Santopietro R, Bindi M, Tucci E, Barbini P, Baak JPA: Correlation between morphometrical parameters and disease-free survival in ductal breast cancer treated by surgery. Appl Pathol 1986, 4:33-42.

139. Sarker S: Mean nuclear area of fine needle aspirates of primary preoperative palpable breast carcinoma using image cytometry. Anal Quant Cytol Histol 2002, 24(2):85-8.

140. Kronqvist P, Kuopio T, Collan Y: Morphometric grading of invasive ductal breast cancer. I. Thresholds for nuclear grade. $B$ J Cancer 1998, 78(6):800-5.

14I. Gonzalez MA, Pinder SE, Wencyk PM, Bell JA, Elston CW, Nicholson RI, Robertson JF, Blamey RW, Ellis IO: An immunohistochemical examination of the expression of E-cadherin, alpha- and beta/gamma-catenins, and alpha2- and betal-integrins in invasive breast cancer. J Pathol 1999, 187(5):523-9.

142. Lipponen P, Saarelainen E, Ji H, Aaltomaa S, Syrjanen K: Expression of E-cadherin (E-CD) as related to other prognostic factors and survival in breast cancer. J Pathol I994, 174(2): I0I-9.
143. Asgeirsson KS, Jonasson JG, Tryggvadottir L, Olafsdottir K, Sigurgeirsdottir JR, Ingvarsson S, Ogmundsdottir HM: Altered expression of E-cadherin in breast cancer. patterns, mechanisms and clinical significance. Eur I Cancer 2000:1098-106.

144. Siitonen SM, Kononen JT, Helin HJ, Rantala IS, Holli KA, Isola JJ: Reduced E-cadherin expression is associated with invasiveness and unfavorable prognosis in breast cancer. Am J Clin Pathol 1996, 105(4):394-402.

145. Asgeirsson KS, Olafsdottir K, Jonasson JG, Ogmundsdottir HM: The effects of IL-6 on cell adhesion and e-cadherin expression in breast cancer. Cytokine 1998:720-8.

146. Berx G, Van Roy F: The E-cadherin/catenin complex: an important gatekeeper in breast cancer tumorigenesis and malignant progression. Breast Cancer Res 200I, 3(5):289-93.

147. Charpin C, Garcia S, Bouvier C, Devictor B, Andrac L, Choux R, Lavaut $M$ : E-cadherin quantitative immunocytochemical assays in breast carcinomas. J Pathol 1997, I 8 I (3):294-300

148. Bankfalvi A, Terpe HJ, Breukelmann D, Bier B, Rempe D, Pschadka G, Krech R, Lelle RJ, Boecker W: Immunophenotypic and prognostic analysis of $E$-cadherin and beta-catenin expression during breast carcinogenesis and tumour progression: a comparative study with CD44. Histopathology 1999, 34(I):25-34.

149. Gamallo C, Palacios J, Suarez A, Pizarro A, Navarro P, Quintanilla M, Cano A: Correlation of E-cadherin expression with differentiation grade and histological type in breast carcinoma. Am J Pathol 1993, 142(4):987-93.

150. Elzagheid A, Kuopio T, Ilmen M, Collan Y: Prognostication of invasive ductal breast cancer by quantification of E-cadherin immunostaining: the methodology and clinical relevance. Histopathology 2002, 4 I (2): I27-33.

I5I. Rakha EA, Abd El Rehim D, Pinder SE, Lewis SA, Ellis IO: E-cadherin expression in invasive non-lobular carcinoma of the breast and its prognostic significance. Histopathology 2005, 46(6):685-93

152. Hirohashi S: Inactivation of the E-cadherin-mediated cell adhesion system in human cancers. Am J Pathol 1998 , I53(2):333-9.

153. Ghadimi BM, Behrens J, Hoffmann I, Haensch W, Birchmeier W, Schlag PM: Immunohistological analysis of E-cadherin, alpha-, beta- and gamma-catenin expression in colorectal cancer: implications for cell adhesion and signaling. Eur J Cancer 1999, 35(I):60-5.

154. Yoshida R, Kimura N, Harada Y, Ohuchi N: The loss of E-cadherin, alpha- and beta-catenin expression is associated with metastasis and poor prognosis in invasive breast cancer. Int J Oncol 200I, I 8(3):5I3-20.

155. Lim SC, Lee MS: Significance of E-cadherin/beta-catenin complex and cyclin DI in breast cancer. Oncol Rep 2002:915-28.

156. Foekens JA, Dall P, Klijn JG, Skroch-Angel P, Claassen CJ, Look MP, Ponta H, Van Putten WL, Herrlich P, Henzen-Logmans SC: Prognostic value of CD44 variant expression in primary breast cancer. Int J Cancer 1999, 84(3):209-15.

157. Morris SF, O'Hanlon DM, McLaughlin R, McHale T, Connolly GE, Given HF: The prognostic significance of CD44s and CD44v6 expression in stage two breast carcinoma: an immunohistochemical study. Eur J Surg Oncol 200I, 27(6):527-3I.

158. Joensuu H, Klemi PJ, Toikkanen S, Jalkanen S: Glycoprotein CD44 expression and its association with survival in breast cancer. Am J Pathol 1993, I 43(3):867-74.

159. Tempfer C, Losch A, Heinzl H, Hausler G, Hanzal E, Kolbl H, Breitenecker G, Kainz C: Prognostic value of immunohistochemically detected CD44 isoforms CD44v5, CD44v6 and CD44v7-8 in human breast cancer. Eur J Cancer 1996, 32A(I I):2023-5.

160. Moch H, Torhorst J, Durmuller U, Feichter GE, Sauter G, Gudat F: Comparative analysis of the expression of tenascin and established prognostic factors in human breast cancer. Pathol Res Pract 1993, 189(5):510-4.

16I. Shoji T, Kamiya T, Tsubura A, Hamada Y, Hatano T, Hioki K, Morii S: Tenascin staining positivity and the survival of patients with invasive breast carcinoma. I Surg Res 1993, 55(3):295-7.

162. Yoshida T, Ishihara A, Hirokawa Y, Kusakabe M, Sakakura T: Tenascin in breast cancer development - is epithelial tenascin a marker for poor prognosis? Cancer Lett 1995, 90(I):65-73. 
163. Hidalgo M, Eckhardt SG: Development of matrix metalloproteinase inhibitors in cancer therapy. J Natl Cancer Inst 200I, 93(3): 178-93.

164. Vihinen PP, Pyrhonen SO, Kahari VM: New prognostic factors and developing therapy of cutaneous melanoma. Ann Med 2003, 35(2):66-78

165. Vihinen P, Kahari VM: Matrix metalloproteinases in cancer: prognostic markers and therapeutic targets. Int J Cancer 2002, 99(2): 157-66.

166. Talvensaari-Mattila A, Paakko P, Hoyhtya M, Blanco-Sequeiros G, Turpeenniemi-Hujanen T: Matrix metalloproteinase-2 immunoreactive protein: a marker of aggressiveness in breast carcinoma. Cancer 1998, 83(6): I I53-62.

167. Voltersvik P, Bostad L, Dyrhol-Riise AM, Eide GE, Rosok BI, Olofsson J, Asjo B: Cystatin A and HIV-I p24 antigen expression in tonsillar lymphoid follicles during HIV-I infection and during highly active antiretroviral therapy. J Acquir Immune Defic Syndr 2006, 4 I(3):277-84.

168. Lah TT, Kos J, Blejec A, Frkovic-Georgio S, Golouh R, Vrhovec II, Turk VV: The Expression of Lysosomal Proteinases and Their Inhibitors in Breast Cancer: Possible Relationship to Prognosis of the Disease. Pathol Oncol Res 1997, 3(2):89-99.

169. Greenough RB: Varying degrees of malignancy in cancer of the breast. J Cancer Res 1925, 9:452-463.

170. Patey DH, Scarff RW: The position of histology in the prognosis of carcinoma of the breast. Lancet |928, I:80|-804.

171. Bloom HJG, Richardson WW: Histological grading and prognosis in breast cancer. A study of 1409 cases of which $\mathbf{3 5 9}$ have been followed for I 5 years. Br / Cancer 1957, I I:359-377.

172. Elston CW, Ellis IO: Pathological prognostic factors in breast cancer. I. The value of histological grade in breast cancer: experience from a large study with long-term follow-up. Histopathology 1991, 19(5):403-10.

173. Page DL, Jensen RA, Simpson JF: Premalignant and malignant disease of the breast: the roles of the pathologist. Mod Pathol 1998, II(2): 120-8. Review

174. Cianfrocca M, Goldstein LJ: Prognostic and predictive factors in early-stage breast cancer. Oncologist 2004, 9(6):606-16. Review

175. Kronqvist P, Kuopio T, Collan Y: Morphometric grading of breast cancer: thresholds for tubular differentiation. $\mathrm{Br} J \mathrm{Can}-$ cer 2000, 82(10): |656-6I.

176. Stenkvist B, Bengtsson E, Dahlqvist B, Eklund G, Eriksson O, Jarkrans T, Nordin B: Predicting breast cancer recurrence. Cancer 1982, 50(12):2884-93.

177. Eskelinen M, Collan Y, Pajarinen P, Pesonen E, Kettunen K, Nordling $S$ : An improved prognostic index of axillary node involvement in breast cancer incorporating DNA ploidy and tumour size. Acta Chir Scand 1990, I 56(8):521-7.

178. Collan YU, Eskelinen MJ, Nordling SA, Lipponen P, Pesonen E, Kumpusalo LM, Pajarinen P, Kettunen KO: Prognostic studies in breast cancer. Multivariate combination of nodal status, proliferation index, tumor size, and DNA ploidy. Acta Oncol 1994, 33(8):873-8.

179. Collan Y, Kuopio T, Auranen A, Linna M: Prognostication of breast cancer by multivariate methods. Adv Clin Path 1997, I(4):269-273.

180. Moureau-Zabotto L, Bouchet C, Cesari D, Uzan S, Lefranc JP, Antoine M, Genestie C, Deniaud-Alexandre E, Bernaudin JF, Touboul E, Fleury-Feith J: Combined flow cytometry determination of Sphase fraction and DNA ploidy is an independent prognostic factor in node-negative invasive breast carcinoma: analysis of a series of 27 I patients with stage I and II breast cancer. Breast Cancer Res Treat 2005, 9 I(I):6I-7I.
Publish with Biomed Central and every scientist can read your work free of charge

"BioMed Central will be the most significant development for disseminating the results of biomedical research in our lifetime. "

Sir Paul Nurse, Cancer Research UK

Your research papers will be:

- available free of charge to the entire biomedical community

- peer reviewed and published immediately upon acceptance

- cited in PubMed and archived on PubMed Central

- yours - you keep the copyright

Submit your manuscript here:

http://www.biomedcentral.com/info/publishing_adv.asp
BioMedcentral 